\title{
EVOLUTION IN BANKING COMPETITION
}

\author{
Walter A. Varvel and Henry C. Wallich*
}

The Supreme Court view of commercial banking as a "distinct line of commerce" no longer reflects market realities in many sections of the United States. The argument used by the Court to support its findings were not universally endorsed at the time. Today they have been sufficiently eroded by changing competitive conditions and financial innovations in the markets for financial services to require a reassessment of the competitive position of commercial banks.

The "line of commerce" view remains an integral part of the competitive analysis conducted by federal banking agencies in connection with proposed bank mergers and acquisitions. Supreme Court determinations of the appropriate definitions of the product linc and geographic markets in banking directly influence the market structure variables that are used by regulators as indicators of market competition. Experience over the last two decades has led regulators to the general view that, for competitive analysis purposes, banks can be considered to compete only with other banks.

Commercial banking has been treated as a separate line of commerce because it was thought to offer a unique package or "cluster" of independent depository and credit services to bank customers. This treatment has the effect of excluding from definitions of product markets firms that compete with banks in some but not all service lines. For example, in their role as financial intermediaries, banks face competition for funds from other depository institutions as well as from a myriad of liability instruments offered in the money market. Moreover, on the asset side of the balance sheet, bank credit is offered in competition with thrift institutions, nonbank firms such as finance and insurance companies, and retailers, as well as the markets for securities and commercial paper. Exclusion of this competition may at times result in overstatements of anticipated anticompetitive results from bank consolidations.

\footnotetext{
* Henry C. Wallich is a member of the Board of Governors of the Federal Reserve System.

Note: "Evolution in Banking Competition" by Henry $\mathrm{C}$ Wallich and Walter $A$. Varvel is reprinted from The Bankers Magazine, 163 (November-December 1980)
}

Innovations in the financial sector are undermining the line of commerce view by eliminating unique banking services and reducing interdependence among banking products. Developments encouraging the separate pricing and marketing of banking services are further increasing the effective competition between banks and other providers of financial services. Recent legislation extends interest-bearing transaction account authority nationwide to thrift institutions, substantially expands the scope of their activities, and provides for the phase-out of deposit interest rate ceilings. In this environment, a reevaluation of competitive analysis in banking is necessary to ensure that it reflects the realities of the marketplace.

The Supreme Court Position: Product and Geographic Markets The Supreme Court, in ruling that commercial banking is the relevant "line of commerce" in bank merger cases, ${ }^{1}$ relied upon the following arguments: (1) some bank products and services are so distinctive that they are essentially free of effective competition from other financial institutions; (2) other bank products and services enjoy cost advantages that insulate them from competition from substitutes offered by other institutions ; (3) banking facilities enjoy a "scttled consumer preference" that gives them an advantage over similar nonbank services; and (4) the "cluster" of products and services termed commercial banking has economic significance well beyond the various products and services involved.

In the Philadelphia National Bank case, the Court declared that banks offer a cluster of products (various kinds of credit) and services (such as checking accounts and trust services) that are "so distinctive that they are entirely free of effective competition from products or services of other financial institutions." In the Court view, banks played a vital and unique role in the national economy since they alone were permitted to accept demand deposits. This

\footnotetext{
1 See the following Supreme Court decision's: United States v. Philadelphia National Bank, 374 U.S. 321 (1963); United States v. Phillipsburg National Bank, 399 U.S. 350 (1970); and United States v. Connecticut National Bank, 418 U.S. 656 (1974).
} 
distinctive power made banks the intermediaries in most financial transactions. As chief repositories for consumer and commercial liquid balances; banks facilitate the efficient transfer of funds from units with surplus funds (creditors) to deficit units (borrowers). Our fractional reserve system, moreover, allows banks to create new money (deposits) and credit and magnifies banks' importance to the economy.

Control of the checking account system was believed by the Court to invest banks with such advantages as to necessitate customer relations with banks. Checking account powers were sufficiently important to distinguish banks from the institutions that most closely resembled them, the thrifts. Later, in the Connecticut case where thrifts had recently received authority to offer check-like Negotiable Order of Withdrawal (NOW) accounts to individuals, the Court again rejected inclusion of savings banks in the same product line as banks since Connecticut savings banks could not provide comparable commercial services to business customers.

In the Philadelphia case, the Court found that in other product lines (e.g., small consumer loans) banks held a competitive advantage over financial institutions that offered similar products. Banks, the Court argued, relied upon lower cost funds (i.e., demand and savings deposits) than did their chief rivals in this market (consumer finance companies) who purchased funds at market interest rates, in substantial part, from banks. As stated by the Court, the reason for this competitive disadvantage is that "only banks obtain the bulk of their working capital without having to pay interest .... thereon, by virtue of their unique power to accept demand deposits. ..."

Cost differentials have not been consistently cited by the Court, however, to distinguish between bank and competitor services. Regulation $Q$ authorizes thrift institutions to pay an interest premium on savings and small time deposits (presently $1 / 4$ percent) above what banks can offer on identical instruments: The Court did not believe this provided a significant competitive advantage to thrifts, however, in the rivalry for depositors' funds. On the contrary, bank savings retained the advantage of "settled consumer preference" "due to coincident checking account relationships. In the Court's words, "customers are likely to maintain checking and savings accounts in the same local bank even when higher savings interest is available elsewhere." Since thrifts were not authorized to offer checking accounts, it was reasoned, consumers were willing to forego some interest for the convenience of one-stop banking.
Most importantly, perhaps, the Court has held that it is the cluster of products and services that fullservice banks offer that makes banking a distinct line of commerce.

Commercial banks are the only financial institutions in which a wide variety of financial products and services-some unique to commercial banking and others not-are gathered together in one place. The clustering of financial products and services in banks facilitates convenient access to them for all banking customers. For some customers, fullservice banking makes possible access to certain products or services that would otherwise be unavailable to them. ...

The department store nature of banks, in other words, represents the only meaningful alternative for a significant class of customers-reducing the effective competition provided by nonbank firms. The Court recognizes that banks do face direct competition in some individual product and service lines, or submarkets (savings, personal loans, mortgage lending, etc.). Such submarkets, however, "are not a basis for the disregard of a broader line of commerce that has economic significance."

In the Court's view, one-stop banking provides individual bank customers with unique access to the wide range of financial services a bank offers. Maintaining a personal checking account, for example, provides a customer with access to a wide range of other bank services, to seek free financial advice from bank management, and increases the chances of obtaining credit when needed. These services would not be available to a significant number of customers outside of the banking relationship, the Court argued. In addition, since customer-bank relationships were usually established because of locational convenience (near residence, employment, or within shopping patterns); bank customers could minimize the time and resources expended (transactions costs) searching for and obtaining financial services. In this way, the Court believed banks maintained a competitive advantage over thrifts and nondepository institutions and, therefore, the aggregate of bank products and services should be treated as the relevant product line for competitive analysis in bank consolidation proposals.

The uniqueness of some commercial bank products and services, cost advantages, "consumer preference," one-stop banking, and the importance of locational

\footnotetext{
2 The Court declared that analysis of individual submarkets are appropriate, however, when considering the effect on competition of a merger between a commercial bank and another type of financial institution. United States v. Phillipsburg National Bank.
} 
convenience have been the dominant considerations in the Court's position on the appropriate definition of the product market in bank merger cases. Locational convenience has also played a key role in Court and regulatory definitions of the geographic markets in competitive analyses.

The Philadelphia National Bank Case In United States v. Philadelphia National Bank, the Supreme Court stated that the area of effective competition in the known line of commerce must be selected from the market area in which the seller operates and to which the buyer can practicably turn for supplies. In banking, the Court observed that individuals and businesses typically do most of their business with banks in their local communities since they find it impractical to conduct their banking business at a distance.

The Court recognized that individual bank customers, however, have different capabilities in shopping for banking services_-"the relevant geographical market is a function of each separate customer's economic scale." In general, said the Court, "the smaller the customer, the smaller is his banking market geographically." In the Court's view, both small borrowers and depositors were largely limited to their localities for the satisfaction of their financial needs. Large customers, on the other hand, often have convenient access to banking services outside the local area.

Since the economic scale of consumers of bank services varies, the Court settled on a "workable compromise" to "delineate the area in which bank customers that are neither very large nor very small find it practical to do their banking business." The Court acknowledged that this compromise could only approximate the geographic scope of the relevant market, and that "an element of fuzziness would seem inherent in any attempt to delineate the relevant geographical market." The use of a single "fuzzy" approximation of the geographic market flows directly from the choice of a single product line in banking - the cluster of bank products and services. Clearly, a disaggregated product line (e.g., demand deposits, consumer installment loans, commercial loans, etc.) might dictate the use of multiple geographic markets for analytical purposes, depending on the respective geographic areas over which the customers might practicably turn for alternative supplies.

To date, the Court has agreed with the federal banking agencies that the local area in which the banks had their offices was an area of effective competition. The competitive effects of proposed mergers, therefore, have generally been judged within localized geographic markets.

Analytical Method: Concentration Ratios Section 7 of the Clayton Act requires the banking agencies to determine whether the effect of a proposed merger may be to substantially lessen competition. In the Philadelphia National Bank case, the Court pointed out that a prediction of anticompetitive effects "is sound only if it is based upon a firm understanding of the structure of the relevant market; yet the relevant economic data are both complex and elusive." The Court felt that it was necessary to simplify the competitive analysis in order to provide a guideline for sound business planning and to insure that Congressional intent was not subverted.

In simplifying the test of illegality, the Court relied on a sense of intense Congressional concern with a trend toward concentration in the U. S. economy. This concern, said the Court, "warrants dispensing, in certain cases, with elaburate proof of market structure, market behavior, or probable anticompetitive effects." The Court thought that "a merger which produces a firm controlling an undue percentage share of the relevant market, and results in a significant increase in the concentration of firms in that market, is so inherently likely to lessen competition substantially that it must be enjoined in the absence of evidence clearly showing that the merger is not likely to have such anticompetitive effects." The Court endorsed the use of concentration ratios, therefore, as an indicator of proposed mergers. ${ }^{3}$

The Court accepts bank deposit concentration ratios as prima facie evidence in antitrust cases. The burden of proof is shifted to the banks to show that the ratios do not accurately depict the economic characteristics of the market. The Court requires banks to introduce "significant evidence of the absence of parallel behavior in the pricing or providing of commercial bank services" in the market. This is a

3 The use of concentration ratios is not based solely on
grounds of simplification, but also has some empirical
support. Concentration measures have been positively
related with performance variables such as prices and
profits for a wide range of industries, including banking.
For a summary of this evidence, see Stephen Rhoades,
"Structure and Performance Studies in Banking: A
Summary and Evaluation," Staff Economic Studies, No.
92 , Board of Governors of the Federal Reserve System,
1977. The Structure-Performance relationship has been
questioned, however, by suggestions that concentration,
instead of leading to collusive behavior, actually emerges
from competitive behavior and reflects the superior per-
formance of large firms. For example, see. Yale Brozen,
"The Concentration-Collusion Doctrine," Antitrust Law
Journal (1977-78). 
difficult task since, in the Court's own terms, relevant data is "complex and elusive."4

Competitive analysis has focused on shares of bank deposits (as a proxy for bank products and services) controlled by individual banks. Concentration ratios are calculated in cases involving banks determined to be presently competing within the same geographic market, as well as for cases involving banks operating in separate banking markets but viewed as potential or probable future competitors. In existing competition cases, mergers are generally prohibited if the combined market shares significantly increase concentration in the market. In the latter application, a consolidation is generally not allowed if it either (a) eliminates a procompetitive influence exerted by an outside bank on a concentrated market or (b) removes a likely entrant to a concentrated market that can reasonably be expected to contribute to the future deconcentration of the market.

Effects on Bank Markets The line of commerce view and the resultant analytical methodology have provided close approximations of actual competitive conditions in many banking markets. The policy has undoubtedly preserved competition among banking institutions in numerous markets by limiting banks' ability to buy out competitors. This has contributed to preventing increased banking concentration and possible adverse competitive consequences. In some markets, however, the predicted anticompetitive effects of a merger proposal may be overstated, resulting in denials of cases that could have been approved without significant anticompetitive results.

U. S. antitrust standards declare a consolidation is legal unless it tends to create a monopoly or substantially reduces competition. The concern is to prevent one firm or a small group of firms from gaining sufficient market power to charge monopoly prices and realize monopoly profits. In cases where the Court's view misrepresents the actual competitive situation in the market, however, prohibiting a bank consolidation may represent an unwarranted interference with the free flow of commerce. Competition can be stifled by not allowing bank ownership to pass from inefficient, unaggressive hands to more efficient, innovative control. The number of potential

\footnotetext{
4 Demonstrating an absence of parallel behavior is difficult for products and services subjected to extensive regulatory price restrictions (e.g., prohibition of interest on demand deposits, deposit rate ceilings, and usury laws). Administered rates have regularly fallen below market rates, forcing institutions to uniformly pay (or charge) the maximum allowable rates. Price competition among depository institutions will be much greater following recent legislative changes.
}

bidders for bank stock is reduced by limiting purchase by existing or potential market participants, reducing potential demand for bank stock, and lowering its market value.

Empirical studies indicate that banking is subject to economies of scale, at least for small- and mediumsize banks. As output (measured by the number of accounts serviced) increases, average banking costs generally increase less than proportionally. Banks growing through consolidation, therefore, can often economize on resources used to provide banking services. Bank customers can expect to benefit from lower unit costs either through lower prices and/or service charges for bank products or through access to expanded output. If competitive pressures do not forcc banks to pass on savings to customers, bank profits may increase. Bank capital should benefit through increased retained earnings-enhancing bank asset growth.

The evidence on scale economies in banking has led George Benston to conclude that "unless a merger reduces meaningful competition, it should not be prevented. Otherwise, operating and other inefficiencies may be continued, desirable change stifled, and owners of resources prevented from using their property as they wish." 5 The vast majority of bank merger proposals, it should be noted, fall well within the range where economies might be anticipated. Since real private and social costs can result from prohibiting these consolidations, the analysis used in evaluating the competitive impact on the relevant product market should be sound.

Inherent Weaknesses The central core of the Supreme Court's line of commerce determination is its finding that the entire aggregate of bank products and services represents an economically significant market. "[I]t is the cluster of products and services that full-service banks offer that as a matter of trade reality makes commercial banking a distinct line of commerce."6 This finding and the resulting methodology employed by the Court and banking agencies have been criticized since its inception. We believe this criticism reflects some basic flaws in the Court argument.

In a landmark case involving the definition of a relevant product market, the Court declared that "the

\footnotetext{
5 George Benston, "The Optimal Banking Structure: Theory and Evidence," Journal of Bank Research (Winter 1973), pp, 220-37.

6 United States v. Philadelphia National Bank.
} 
commodities reasonably interchangeable by consumers for the same purposes make up that part of the trade or commerce. ..."7 Based on this standard, it appears the Court has aggregated bank products and services beyond the point where commodities are reasonably interchangeable ${ }^{8}$ by consumers.

The various products and services that banks offer appear to be customer-specific, i.e., they are directed toward specific customer groups. There are at least two distinct categories of customers that use bank services-individuals and commercial enterprises. Banks can be viewed as providing a cluster of consumer products and services to individuals (demand and savings deposits, consumer and mortgage credit, trust services. etc.) and a separate cluster to businesses (cash management services, commercial and industrial loans, etc.). Though individual customers may well benefit from the provision of either of these clusters by a single institution, there is very little reason to expect that individuals or businesses utilize both clusters. There seems to be little or no crossover across cluster categories by customers. The financial needs of each group are distinct and serve to restrict their respective demands to different clusters of bank products and services. Planning and marketing activities reflect this with separate consumer and corporate departments within banks and separate advertising programs. Indeed, many banks have chosen to specialize almost exclusively in either the retail or wholesale sides of the business.

Contrary to the Court's assertion, the entire bank product line, therefore, does not appear to have economic significance-it does not appear to be a relevant market-for it is not marketed to any one class of customers. It is only across the cluster of consumer products and services that the pricing or service level decisions of the commercial bank can have an impact on its consumer clientele.

At the same time, the Court's definition of the line of commerce in conmercial banking excludes products and services of other institutions that are "interchangeable" with or close substitutes for individual

7 United States v. DuPont \& Co., 351 U.S. 377, 395 (1956). The emphasis in this determination, it should be noted, is on the demand characteristics of the consumers of the product.

8 The Court declared that interchangeability can be shown by demonstrating either (a) products perform the same function or (b) the responsiveness of the sales of one product to changes in the price of the other (high price cross-elasticity of demand). If "a high crosselasticity of demand exists between them; . . . the products compete in the same market." bank services. Empirical evidence reveals that a high cross-elasticity of demand exists between bank time deposits and savings deposits at thrifts. Moreover, disintermediation from both bank and thrift deposits, when market interest rates increase relative to deposit rates, indicates that other market instruments are at least partial substitutes for these services. Close substitutes for various bank credit services are similarly offered by nonbank institutions. Banks cannot make pricing decisions without regard to the availability of substitute products from both bank and nonbank institutions. Yet the accepted analytical methodology implies they can.

Use of concentration ratios, including only bank deposits, ignores the competitive influences exerted by thrifts and other institutions that supply substitute services. Since the Court's analysis is not affected by the presence of competition for individual bank services from nonbank firms, the significance of computed concentration percentages has been seriously questioned. The Court "blithely assumes that percentages of the same magnitude represent the same degree of market power, irrespective of the amount of competition from neighboring markets." It thus ignores "the extent to which competition from savings and loan associations, mutual savings banks, and other financial institutions that are not commercial banks affects the market power of banks."

If concentration ratios misrepresent the market power of banks, and the existence of nonbank institutions in the market also affects banks' ability to influence prices, the predictive usefulness of concentration ratios that exclude those institutions is diminished. In particular, judgments based solely on bank deposit concentration, ignoring competitive realities in the market, may overestimate adverse competitive effects, leading to unwarranted denials of bank consolidation proposals.

The Court and banking agencies appear at least aware of the danger of sole reliance on concentration ratios. In a 1974 decision, ${ }^{10}$ the Court acknowledged that concentration ratios "can be unreliable indicators of actual market behavior." In addition, the Comptroller of the Currency and Federal Reserve Board have given limited consideration in recent years to the competitive presence of thrifts in assessing anticompetitive consequences of proposed mergers. Concentration ratios are sometimes "shaded" to reflect

\footnotetext{
9 Justice Harlan, joined in part by Chief Justice Burger, in a dissenting opinion to the Phillipsburg decision.

10 United States v. Marine Bancorporation, 418 U.S. 602 (1974).
} 
significant competition from thrifts when concentration data suggest the case might be borderline. ${ }^{11}$

Erosion by Innovations and New Competition However justified and effective established interpretations have been in preserving and promoting competition for banking services, competitive forces in these markets have not stood still. Today, banks face intensive competition across a rapidly broadening scope of product and geographic markets from other banks, thrifts, and other financial and nonfinancial firms. This evolving competition represents an attempt by the market system to meet the financial requirements of the U. S. economy. Price, product, and geographic restrictions have limited the ability of banks to fulfill these needs and have induced unregulated sectors of the economy to fill the void.

The new competition banks face has seriously undermined the relevance of some of the Court determinations in bank competition cases. Today, banks no longer enjoy a monopoly in the provision of transaction accounts to consumers. At the same time, banks are experiencing an all-out invasion of their other product as well as geographic markets from both traditional and new competitors. In addition, cost advantages banks may have once enjoyed over competitors have largely been eliminated as banks increasingly rely on market sources of funds purchased at market interest rates. The thesis that banks enjoy a "settled consumer preference" over competing institutions is hardly supported by the evidence. Finally, strong economic forces are inducing banks and other institutions to "unbundle" service packages and separately market and price financial services.

The Supreme Court deemed some bank services as so unique that they are entirely free of competition from other financial institutions. Demand deposits, commercial loans, trust services, and credit card plans were cited at various times to distinguish banks from nonbank institutions. Developments in recent years, however, suggest that the strength of this argument has been greatly diminished.

Checking accounts were first subjected to thrift competition when S\&Ls were authorized to allow telephone transfers from savings accounts to third parties in the 1960s. In 1970, S\&Ls were permitted

11 A Board order involving First Bancorp of New Hampshire (November 2, 1978), for example, noted that "thrift institutions held a significant amount of deposits which lessened the severity of the effects of the proposed transaction on competition in the market." More recently, the Board approved a large New Jersey bank merger, citing significant thrift competition as a factor (Fidelity Union Bancorporation, June 5, 1980). to make preauthorized nonnegotiable transfers from savings accounts to third parties for household related expenditures. This authority was expanded to cover any expenditure in 1975 . In a major development in 1972, state chartered mutual savings banks began offering Negotiable Order of Withdrawal (NOW) accounts in Massachusetts and New Hampshire. In 1974, Congress authorized all depository institutions in the two states to offer such accounts, a privilege extended to the remaining New England states in 1976, New York in 1978, and New Jersey in 1979. Pennsylvania savings banks also offered an instrument perceived by the public to be the functional equivalent of checks, the NINOW or noninterest-bearing NOW account. The direct competition between banks and thrifts for these transaction accounts has been fierce.

In response to the apparent success of the NOW experiment, in late 1978 federal regulators authorized automatic transfers from savings to checking accounts nationwide for banks. The Consumer Checking Account Equity Act of 1980 extends NOW account authority nationwide to all federally insured banks, savings banks, and S\&Ls.

Another development of large dimension was the credit union share draft, first authorized on an experimental basis in 1974 and made permanent in 1978. Share drafts and consumer lending powers at credit unions present major new competition for banks, since there are over 22,000 credit unions in the country with total membership including nearly 25 percent of all American households.

The new banking legislation also expands the ability of S\&Ls to compete effectively with banks for consumer business. S\&Ls are newly enabled to diversify their portfolios to hold up to 20 percent of total assets in consumer loans, commercial paper, and corporate debt securities. They are further authorized to engage in credit card operations and to exercise trust powers similar to national banks. These services eliminate several key distinctions between banks and S\&Ls, at least with respect to services offered to consumers.

In addition, S\&Ls do make commercial and business loans secured by real estate and, since the 1960 s, have offered savings accounts to state and local governments and businesses. Savings banks generally have wider authority to provide business services. In several states these institutions can make commercial and business loans. Though these institutions have not presented major competition to bank commercial services to date, the recent legislation authorizing federally chartered savings banks to hold 
up to five percent of their assets in commercial and industrial loans and to accept business demand deposits should give significant impetus to increased competition.

In some key aspects thrifts might even enjoy some competitive advantages ovcr banks. Federally chartered S\&Ls enjoy statewide branching privileges in limited-branching and unit-banking states. In addition, through Remote Service Units, S\&Ls allow customers to make deposits to and withdrawals from accounts at stores and other places away from the institution's offices. The competitive position of thrifts relative to banks is further enhanced by the 1980 Depository Institutions Deregulation Act provision continuing the $1 / 4$ percent differential interest rate ceiling structure for six years.

A second development undermining the Supreme Court arguments supporting the line of commerce view has been the sharp rise in the cost of bank funds. The dominance of noninterest-bearing demand deposits in bank liability structures has been steadily eroded by inflation, high interest rates, and the resulting efforts of consumers and business to economize on holdings of idle, nonearning cash balances. In 1960, demand deposits held by individuals, partnerships, and corporations accounted for 63 percent of total bank liabilities. This figure fell to 40 percent by 1970 and stood at only 31 percent in 1978. ${ }^{12}$ Much of the growth in bank time and savings deposits has taken place in negotiable certificates of deposit and other time deposits, particularly those categories exempted from interest rate ceilings. Banks' commercial customers have further attempted to minimize cash balances through use of repurchase agreements that allow firms to earn market interest on excess transactions balances.

Increased reliance on the Federal funds market and other categories such as Eurodollar borrowings have also expanded the portion of bank funds acquired under market conditions. The result has been a sharp increase in banks' marginal cost of funds. Since the marginal cost of funds is the prime determinant of bank prices, competitive cost advantages banks once may have enjoyed over nonbank competitors such as finance companies have largely evaporated. In addition, it is not true today that finance companies rely on bank loans as a major source of funds. These companies derive most of their funds from the corporate debt and commercial

12 Marvin Goodfriend, James Parthemos, and Bruce Summers, "Recent Financial Innovations: Causes, Consequences for the Payments System, and Implications for Monetary Control," Economic Review, Federal Reserve Bank of Richtnond (March/April 1980). paper markets, with bank loans accounting for only a small portion.

Relative growth rates of savings deposits in recent years also calls into question the Court argument that banks enjoy a "settled consumer preference" in the compctition for consumers' savings due to the convenience of maintaining savings and checking accounts at one institution. Recognizing that competition for the savings dollar among banks and thrift institutions had increased, a 1968 District Court decision ${ }^{13}$ concluded that a settled consumer preference no longer prevailed. Competition among these institutions, therefore, was required to be reflected in the concentration ratios used to measure competition.

The nationwide extension of transaction accounts to thrifts suggests these institutions may be the ultimate beneficiaries of "consumers' preference" in the coming years. Though banks and thrifts can both pay $5 \mathrm{r} / 4$ percent interest on NOW accounts, thrifts are initially pricing this service more liberally than banks (lower minimum balance requirements, etc.). Continuation of the interest differential on savings along with more liberal branching authority in many states may provide a competitive advantage for thrifts. In addition, credit union share drafts pay higher interest than NOW or ATS accounts. We might expect to see, therefore, an acceleration of growth of savings and small time deposits at thrifts relative to commercial banks.

Finally, economic conditions, innovations in financial markets, and new technology are breaking down traditional methods of marketing banking services. Banking customers are more interest-sensitive than ever bcforc and are demanding higher yields for surplus funds. In response, the financial system is clearly moving toward payment of market rates for all categories of funds. Institutions resisting this trend will experience a reduced ability to attract customers. Government policymakers recognize that restrictions on depository institutions' ability to pay market rates on deposits has contributed greatly to the rapid growth of "near-deposit" market instruments, most notably money market fund shares that reached the $\$ 80$ billion asset level by mid-1980. These funds provide a highly liquid, low denomination investment yielding a market return not subject to Regulation $Q$ or deposit reserve requirements. To a limited degree, they can even be used as transaction accounts.

In this new environment, an increasing proportion

13 United States v. Provident National Bank, 280 F Supp. 1 E. D. Pa. 1968. 
of bank business will likely be conducted on an explicit price basis. Customers receiving market interest on deposits can expect to pay full-cost prices for other services provided by their depository institutions. It may no longer be feasible for firms to offer a wide range of specialized services to their depositors free or at subsidized prices. Another force contributing to this result is recent legislation requiring the Federal Reserve System to charge explicit, per-unit prices for the payment system services provided to depository institutions. These charges, by necessity, will also be passed on to customers.

The emergence of an explicit pricing environment should contribute to the further "unbundling" of bank products and services. Explicit pricing may also reduce customers' costs of obtaining information about financial services. This may reduce the importance of locational convenience in banking relationships-especially in an electronic banking environment.

Electronic Funds Transfer Systems are reducing the importance of one-stop banking. Proliferation of credit and debit cards, preauthorized transfers, automated teller machines, point-of-sale terminals, as well as telephone and mail banking, expand the geographic scope of the "locally-limited" customer and increase the ability of distant institutions to provide effective competition in local areas. As a result, increased scrutiny of geographic as well as product markets will be required in bank consolidation cases.

Changes in Competitive Analysis Some disaggregation of the relevant bank product line seems necessary, therefore, before economically relevant markets can be defined for antitrust purposes. At the same time, significant competition from nonbank firms that affects banks' ability to set prices and service levels must be included in the competitive analysis. We are not suggesting total disaggregation and examination of concentration ratios for every individual service line. Some aggregation still seems relevant. For instance, treating the consumer and commercial (or retail and wholesale) sides of banking as separate lines of commerce would allow an analysis of competition in the products and services produced by institutions separated according to the types of customers that use them. This treatment would appear consistent with the emphasis the Court placed on customer demand characteristics in its definition of a relevant product market in United States v. DuPont.

Disaggregation and analysis of multiple product markets will require careful evaluation of the relevant geographical markets over which customers can "practicably turn for supplies." Clearly, the potential of electronic banking and the possibilities of relaxing prohibitions on interstate banking in the near future will blur geographic delineations and require an intensified research effort in this area.

It is our belief that there is no longer sufficient justification for excluding thrift institutions from the competitive analysis in markets for consumer services. These institutions have now attained the status of being fully competitive with banks. In fact, until the interest differential on savings and branching differences are eliminated, thrifts may even enjoy a clear advantage in competing for consumer business. Their deposits should be included, therefore, in the calculation of concentration ratios for antitrust purposes.

Considering the limitations placed on the ability of savings and loan associations and credit unions to compete for commercial business, however, these institutions can probably continue to be excluded from the analysis of the market for commercial services. This may not be the case for mutual savings banks with their commercial lending and deposit-taking powers. The Supreme Court apparently anticipated the inclusion of these institutions as competitors with banks: "At some stage in the development of savings banks it will be unrealistic to distinguish them from commercial banks for purposes of the Clayton Act. In Connecticut, that point may well be reached when and if savings banks become significant participants in the marketing of bank services to commercial enterprises."14

A disaggregation of the product line into consumer and commercial categories would require dual analyses, possibly involving the use of an expanded geographic market definition for business services. With this methodology it might be possible to conclude, for instance, that a proposed acquisition would have no significantly adverse competitive consequences on the market for consumer banking services (based on personal deposit market shares) while the impact on the business product line (based on business deposits or commercial loan shares) warrants denial of the application.

The above suggestions are by no means definitive. They are viewed merely as the minimum changes necessary at the present time to reflect competitive reality in the marketplace. They may only represent the initial recognition on the part of the Courts and the regulators of the evolution underway in banking competition.

14 United States v. Connecticut National Bank. 


\title{
COMMERCIAL PAPER
}

\author{
Peter A. Abken
}

Commercial paper is a short-term unsecured promissory note that is generally sold by large corporations on a discount basis to institutional investors and to other corporations. Since commercial paper is unsecured and bears only the name of the issuer, the market has generally been dominated by large corporations with the highest credit ratings. In recent years commercial paper has attracted much attention because of its rapid growth and its use as an alternative to short-term bank loans. The number of firms issuing commercial paper rose from slightly over 300 in 1965 to about 1,000 in 1980. Moreover, the outstanding volume of commercial paper increased at an annual rate of 12.4 percent during the 1970 s to a level of $\$ 123$ billion in June 1980. This article describes the commercial paper market, focusing primarily on the 1970 s, the period of greatest change and growth.

Market Characteristics The principal issuers of commercial paper include finance companies, nonfinancial companies, and bank holding companies. These issuers participate in the market for different reasons and in different ways. Finance companies raise funds on a more-or-less continuous basis in the commercial paper market to support their consumer and business lending. These commercial paper sales in part provide interim financing between issues of long-term debentures. Nonfinancial companies issue commercial paper at less frequent intervals than do finance companies. These firms issue paper to meet their funding requirements for short-term or seasonal expenditures such as inventories, payrolls, and tax liabilities. Bank holding companies use the commercial paper market to finance primarily bankingrelated activities such as leasing, mortgage banking, and consumer finance.

Denominations and Maturities Like other instruments of the money market, commercial paper is sold to raise large sums of money quickly and for short periods of time. Although sometimes issued in denominations as small as $\$ 25,000$ or $\$ 50,000$, most commercial paper offerings are in multiples of $\$ 100,000$. The average purchase size of commercial paper is about $\$ 2$ million. The average issuer has
$\$ 120$ million in outstanding commercial paper; some of the largest issuers individually have several billion dollars in outstanding paper.

Exemption from registration requirements with the Securities and Exchange Commission reduces the time and expense of readying an issue of commercial paper for sale. Almost all outstanding commercial paper meets the conditions for exemption, namely: (1) that it have an original maturity of no greater than 270 days and (2) that the proceeds be used to finance current transactions. The average maturity of outstanding commercial paper is under 30 days, with most paper falling within the 20- to 45-day range.

Placement Issuers place commercial paper with investors either directly using their own sales force or indirectly using commercial paper dealers. The method of placement depends primarily on the transaction costs of these alternatives. Dealers generally charge a one-eighth of one percent commission on face value for placing paper. Therefore, if a firm places $\$ 100$ million in commercial paper using the intermediary services of a dealer, commissions would cost $\$ 125$ thousand. There are six major commercial paper dealers.

Firms with an average amount of outstanding commercial paper of several hundred million dollars or more generally find it less costly to maintain a sales force and market their commercial paper directly. Almost all direct issuers are large finance companies. The short-term credit demands of nonfinancial companies are usually seasonal or cyclical in nature, which lessens the attractiveness of establishing a permanent commercial paper sales staff. Consequently, almost all nonfinancial companies, including large ones, rely on dealers to distribute their paper.

There is no active secondary market in commercial paper. Dealers and direct issuers may redeem commercial paper before maturity if an investor has an urgent demand for funds. However, dealers and direct issuers discourage this practice. Early redemptions of commercial paper rarely occur primarily because the average maturity of commercial paper is so short. One major commercial paper dealer estimates that only about two percent of their outstanding commercial paper is redeemed prior to maturity. 
Quality Ratings The one thousand or so firms issuing paper obtain ratings from at least one of three services, and most obtain two ratings. The three rating companies that grade commercial paper borrowers are Moody's Investors Service, Standard \& Poor's Corporation, and Fitch Investor Service. Table I shows the number of companies rated by Moody's, classified by industry. This table, covering 881 issuers, gives a good indication of the industry grouping of issuers. Moody's describes its ratings procedure as follows:

Moody's evaluates the salient features that affect a commercial paper issuer's financial and competitive position. Our appraisal includes, but is not limited to the review of factors such as: quality of management, industry strengths and risks, vulnerability to business cycles, competitive position, liquidity measurements, debt structure, operating trends, and access to capital markets. Differing weights are applied to these factors as deemed appropriate for individual situations. ${ }^{1}$

The other rating services use similar criteria in evaluating issuers. From highest to lowest quality, paper ratings run: $\mathrm{P}-1, \mathrm{P}-2, \mathrm{P}-3$ for Moody's; $\mathrm{A}-1, \mathrm{~A}-2$, A-3 for Standard \& Poor's; and F-1, F-2, F-3 for Fitch. For all rating services as of mid-1980, the average distribution of outstanding commercial paper for the three quality gradations was about 75 percent for grade 1, 24 percent for grade 2, and 1 percent for grade 3. As will be discussed below, the difference in ratings can translate into considerable differences in rates, particularly during periods of financial stress.

The multifaceted rating system used by Moody's reflects the heterogeneous financial characteristics of commercial paper. Paper of different issuers, even with the same quality rating, is not readily substitutable. Consequently, commercial paper tends to be difficult to trade, and bid-asked spreads on paper of a particular grade and maturity run a wide $1 / 8$ of a percentage point.

Backup Lines of Credit In. most cases, issuers back their paper 100 percent with lines of credit from commercial banks. Even though its average maturity is very short, commercial paper still poses the risk than an issuer might not be able to pay off or roll over maturing paper. Consequently, issuers use a variety of backup lines as insurance against periods of financial stress or tight money. These credit lines are contractual agreements that are tailored to issu-

1 Sumner N. Levin, ed., The 1979 Dow Jones-Irwin Business Almanac (Homewood, Ill.: Dow Jones-Irwin, 1979), pp. 256-57.
Table I

\section{INDUSTRY GROUPING OF COMMERCIAL PAPER ISSUERS RATED BY MOODY'S}

November 3, 1980

\begin{tabular}{|c|c|c|}
\hline Industry Grouping & $\begin{array}{c}\text { Number } \\
\text { of Firms } \\
\text { Rated } \\
\end{array}$ & $\begin{array}{c}\text { Percentage } \\
\text { of Total } \\
\text { Firms Rated }\end{array}$ \\
\hline Industrial & 370 & 42.0 \\
\hline Public Utilities & 193 & 21.9 \\
\hline Finance & 155 & 17.6 \\
\hline Bank Holding & 119 & 13.6 \\
\hline Mortgage Finance & 9 & 1.0 \\
\hline Insurance & 25 & 2.8 \\
\hline Transportation & 10 & 1.1 \\
\hline Total & 881 & 100.0 \\
\hline
\end{tabular}

Source: Moody's Bond Survey, Annual Review.

ers' needs. Standard credit line agreements allow commercial paper issuers to borrow under a 90 -day note. Swing lines provide funds over very short periods, often to cover a shortfall in the actual proceeds of paper issued on a particular day. Revolving lines of credit establish credit sources that are available over longer periods of time, usually several years.

Noninterest Costs of Issuing Commercial Paper There are three major noninterest costs associated with commercial paper: (1) backup lines of credit, (2) fees to commercial banks, and (3) rating services fees. Payment for backup lines is usually made in the form of compensating balances, which generally equal about 10 percent of total credit lines extended plus 20 percent of credit lines activated. Instead of compensating balances, issuers sometimes pay straight fees ranging from $3 / 8$ to $3 / 4$ percent of the line of credit; this explicit pricing procedure has been gaining acceptance in recent years. Another cost associated with issuing commercial paper is fees paid to the large commercial banks that act as issuing and paying agents for the paper issuers. These commercial banks handle the paper work involved in issuing commercial paper and collect the proceeds from an issue to pay off or roll over a maturing issue. Finally, rating services charge fees ranging from $\$ 5,000$ to $\$ 25,000$ per year to provide ratings for issuers. Foreign issuers pay from $\$ 3,500$ to $\$ 10,000$ per year more for ratings, depending on the rating service. 
Investors Investors in commercial paper include money center banks, nonfinancial firms, investment firms, state and local governments, private pension funds, foundations, and individuals. In addition, savings and loan associations and mutual savings banks have recently been granted authority to invest up to 20 percent of their assets in commercial paper. These groups may buy commercial paper from dealers or directly from issuers, or they may buy shares in short-term investment pools that include commercial paper. Except for scattered statistics, the distribution of commercial paper held by the various investor groups is not precisely known. At year-end 1979 all manufacturing, mining, and trade corporations held outright over $\$ 11$ billion in commercial paper. A substantial but undocumented amount is held by utilities, communications, and service companies. Commercial banks held approximately $\$ 5$ billion in their loan portfolios, while insurance companies had about $\$ 9$ billion. Much commercial paper, about one-third of the total amount outstanding or $\$ 40$ billion, is held indirectly through short-term investment pools, such as money market funds and short-term investment funds operated by bank trust departments. At year-end 1979, short-term investment pools held 32.5 percent of all outstanding commercial paper.

History of Commercial Paper Commercial paper has a history that extends back to colonial times, prior to the existence of a banking system in America. The precursor of commercial paper was the domestic bill of exchange, which was used to finance trade as early as the beginning of the eighteenth century. ${ }^{2}$ Bills of exchange allowed the safe and convenient transfer of funds and provided a shortterm loan between the time of purchase and payment for goods. As financial intermediation evolved, banks and paper brokers began discounting paper. The supply of negotiable paper was held by commercial banks or by entrepreneurs investing surplus funds.

In marked contrast to today's commercial paper market, firms that relied upon commercial paper in earlier times were usually inferior credit risks that could not obtain bank credit. Reflecting this difference in credit risk, commercial paper rates in the early nineteenth century were much higher than bank lending rates. Another basic difference between the early and contemporary commercial paper markets

2 A bill of exchange is an order written by a seller instructing a buyer to pay the seller a specified sum of money on a specified date. is the type of obligation commercial paper represented. Up until the mid-nineteenth century, paper bore both the names of the buyer of goods (the commercial paper issuer) and the seller of goods (the commercial paper drawee), and was issued in odd denominations according to the value of the underlying transaction being financed. Hence, commercial paper was called two-name because if the issuer failed to pay an investor upon maturity of his outstanding paper, it became the obligation of the drawee. As trade and financing practices changed after the Civil War, commercial paper began to be issued extensively as one-name paper, i.e., paper was only the issuer's obligation. ${ }^{3}$ Also, the face value of the paper was unrelated to a specific purchase or shipment of goods and was instead issued in round lot denominations.

From the last quarter of the nineteenth century until the early twentieth, commercial paper allowed borrowers and investors to take advantage of substantial seasonal and more persistent interest rate differentials that existed in different regions of the country. Because of the decentralized banking system that restricted individual banks to particular states and even localities, banks could not readily exploit regional interest rate differentials. However, commercial paper was marketed throughout the country. Commercial banks were able to invest in commercial paper issued in high interest rate areas. Similarly, firms could obtain funds more cheaply by selling commercial paper to banks in low interest rate areas instead of relying entirely on local bank loans. ${ }^{4}$

In the 1920s, commercial paper borrowers included manufacturers, wholesalers, and retailers in a wide variety of product lines. There were about 4,400 firms borrowing in the commercial paper market as a seasonal supplement to bank credit, which was the primary source of funds. Virtually all paper was handled by dealers. Finance companies emerged as major commercial paper borrowers as the automobile industry, sales finance, and small-loan companies grew in importance. In 1920, the largest sales-finance company, General Motors Acceptance Corporation, began to place its paper directly with investors and set maturities specified by investors. Other large finance companies began direct placement about a decade later.

3 For an extensive account of commercial paper's early history, see Albert O. Greef, The Commercial Paper House in the United States (Cambridge: Harvard University Press, 1938), pp. 3-114.

4 Greef, pp. 46, 55, 412-14. 
Commercial banks held by far the largest portion of commercial paper outstanding, which served as a secondary reserve asset. Although no secondary market existed in commercial paper, banks nonetheless regarded paper as highly liquid because the impersonal nature of the credit usually meant there would be no requests for extensions or renewals. Moreover, paper provided banks with an opportunity to diversify their portfolios by industry and geographical area. After 1914, some categories of paper became eligible for discount by the Federal Reserve, which further increased commercial paper's liquidity.

Although the volume of directly placed paper increased during the 1920 s, the total volume of paper outstanding declined. The outstanding volume of commercial paper fell precipitously between 1929 and 1932 from $\$ 420$ million to $\$ 94$ million, as the demand for business credit fell sharply in the Great Depression. In addition, the number of issuers diminished from several thousand to several hundred. From 1933 to the outbreak of World War II, the amount of commercial paper outstanding increased fairly steadily to $\$ 840$ million, reflecting improvement in the general economy, the growing role of consumer credit in financing consumer durables, and the rapid rise of finance companies. Consequently, by 1941 commercial paper outstanding had returned to the levels of the first half of the 1920s. There was a decline in outstanding commercial paper from 1941 to 1945 , however.

The immediate postwar period brought a resurgence in the commercial paper market and by 1951 the market recovered almost to its 1920 peak. The market had changed substantially, however. On the issuer side of the market, directly placed paper, predominantly paper issued by the three largest finance companies, rose to about two-thirds of all paper outstanding by the early 1950 s from about only onefifth at the trough of the Great Depression. - On the investor side, nonfinancial corporations were now beginning to invest liquid assets in commercial paper instead of placing them strictly in demand deposit accounts. Banks were simultaneously relying to a much greater extent on Treasury securities as secondary reserve assets and were no longer the principal purchasers of commercial paper.

Developments Since the Mid-1960s Two events stimulated growth in commercial paper in the 1960 s. First, during the last three quarters of 1966, interest rates rose above Regulation $Q$ ceilings on bank negotiable certificates of deposit (CDs), making it difficult for banks to raise funds to meet the strong corporate loan demand existing at that time. Without sufficient funds to lend, banks encouraged their financially strongest customers to issue commercial paper and offered back-up lines of credit. Many potential commercial paper borrowers who formerly relied exclusively on bank short-term credit now turned to the commercial paper market. Consequently, the annual growth rate of total outstanding commercial paper rose from 7.8 percent in 1965 to 46.6 percent in 1966.

Second, credit market tightness recurred in 1969 as open market interest rates rose above Regulation $Q$ ceilings, again boosting growth in commercial paper. Financial innovation by banks contributed to this growth. The banking system sold commercial paper through bank holding companies, which used the funds to purchase part of their subsidiary banks' loan portfolios. This method of financing new loans resulted in rapid growth in bank-related commercial paper during late 1969 and early 1970, as is seen in Chart 1. The annual growth rate of total outstanding commercial paper more than doubled to 54.7 percent in 1969. In August 1970, the Federal Reserve System imposed a reserve requirement on funds raised in the commercial paper market and channeled to a member bank by a bank holding company, or any of its affiliates or subsidiaries. ${ }^{5}$ As a result, bank related commercial paper outstanding plummeted late in 1970 and early in 1971. This episode, however, marked only the beginning of bank use of commercial paper, which would regain prominence by the mid-1970s.

The Penn Central Crisis The commercial paper market grew steadily during the 1960s. Only five defaults occurred during this decade, the largest of which amounted to $\$ 35$ million. In 1970 , however, the commercial paper market was rocked by Penn Central's default on $\$ 82$ million of its outstanding commercial paper. The default caused investors to become wary of commercial paper issuers and more concerned about their credit worthiness. In the aftermath of the Penn Central default, many corporations experienced difficulty refinancing their maturing commercial paper. Financial disruption was lessened due to a Federal Reserve action which removed Regulation $Q$ interest rate ceilings on 30to 89-day CDs and temporarily liberalized the discount policy for member banks. These actions insured that funds were available from commercial banks to provide alternative financing for corporations having difficulty rolling over commercial paper.

\footnotetext{
5 See page 17 and footnote 6.
} 
After the Penn Central episode, investors became more conscious of credit worthiness and more selective in their commercial paper purchases. During this period, the heightened concern over credit worthiness was evidenced by a widening rate spread between the financially strongest and weakest paper issuers. Although some paper had been rated long before the Penn Central crisis, paper was now rated on a widespread basis.

Interest Rate Controls Wage and price controls imposed during the early 1970s dampened the growth of the commercial paper market. On October 15, 1971, the Committee on Interest and Dividends (CID) established voluntary restraints on

Chart 1

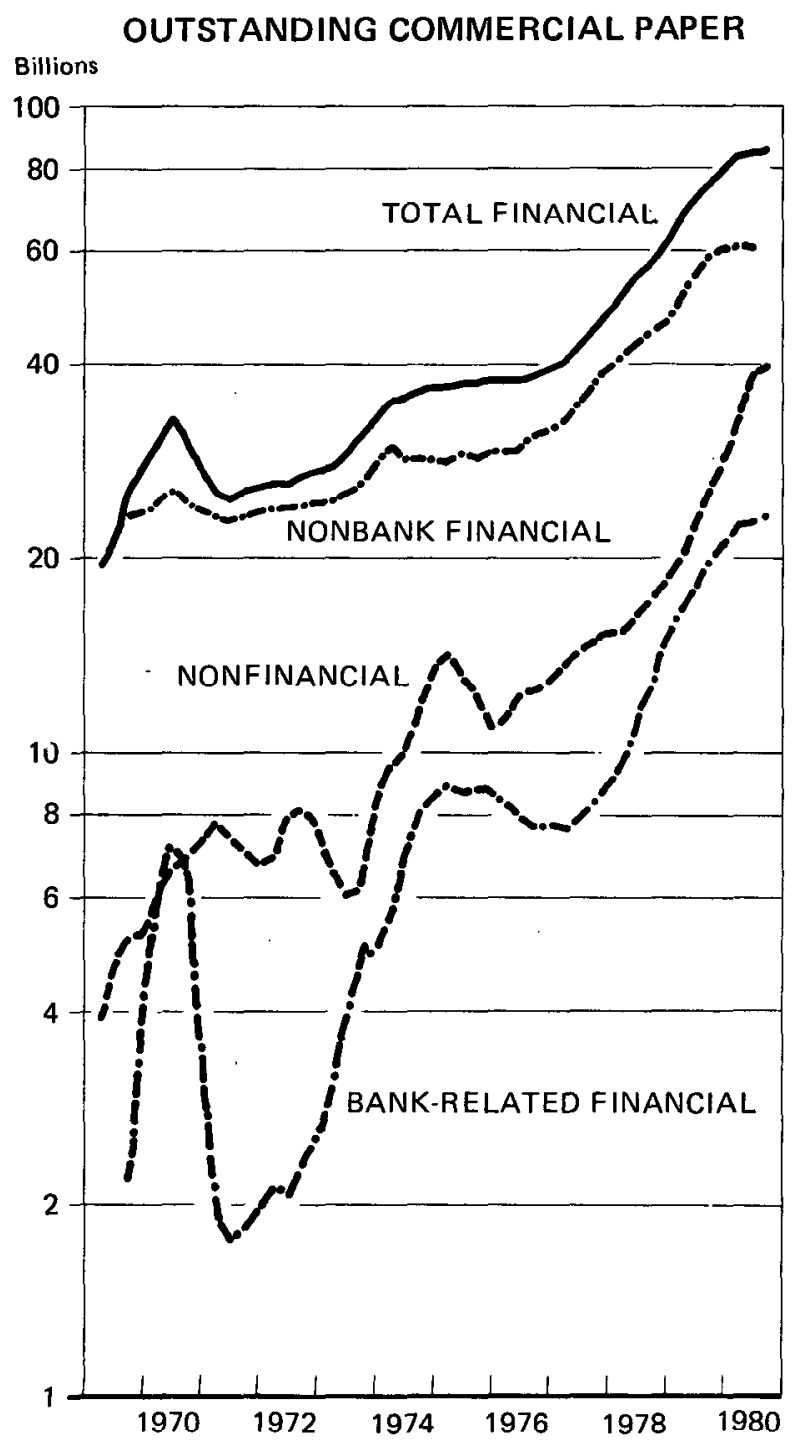

Source: Board of Governors of the Federal Reserve System. "administered" rates, such as the prime rate. No restraints were placed on open market rates, however. This policy triggered flows of funds between controlled and uncontrolled credit markets as the relationship between administered rates and market rates changed. As interest rates rose in 1972, banks came under pressure from the CID to moderate their prime rate increases. By early 1973, the prime rate was held artificially below the commercial paper rate as a consequence of CID policy. Nonfinancial firms substituted short-term bank credit for funds raised through commercial paper issues. Consequently the volume of nonfinancial commercial paper outstanding fell sharply during the first and second quarters of 1973, as is seen in Chart 1. In April of 1973, the CID tried to stem the exodus from the commercial paper market by establishing a dual prime rate. One rate for large firms moved with open market rates, while the other for smaller firms was controlled. Despite these measures, the spread between commercial paper rates and the prime rate persisted and substitution out of paper continued. In the fourth quarter of 1973 CID controls were removed and the commercial paper rate dropped below the prime rate, causing substantial growth in commercial paper. This growth continued throughout 1975 .

The 1973-75 Period The recession of 1973-75 strained the paper market as investors became increasingly concerned about the financial strength of commercial paper issuers. Reflecting this concern, the quality rate spread (the difference between the interest rates on highest quality paper and medium quality paper) rose from about 12 basis points in January 1974 to 200 basis points in November of that year. Chart 2 shows movements in the quality spread from 1974 to 1980 . Utility companies experienced problems selling commercial paper as their ratings were downgraded. Real Estate Investments Trusts (REITs) were another group to encounter problems in the commercial paper market. Loan defaults and foreclosure proceedings early in the recession led to financial difficulties and resulted in a downgrading of REIT paper. As a result, many REITs and utilities were forced to turn to bank credit.

Bank holding companies also experienced difficulty issuing commercial paper in the spring of 1974 . The failure of Franklin National Bank caused widespread concern about the strength of other banking organizations. As a consequence, smaller bank holding companies in particular found it hard to place their paper. Nonetheless, the aggregate volume of outstanding bank-related commercial paper remained 
YIELDS AND SPREADS ON 30-DAY COMMERCIAL PAPER

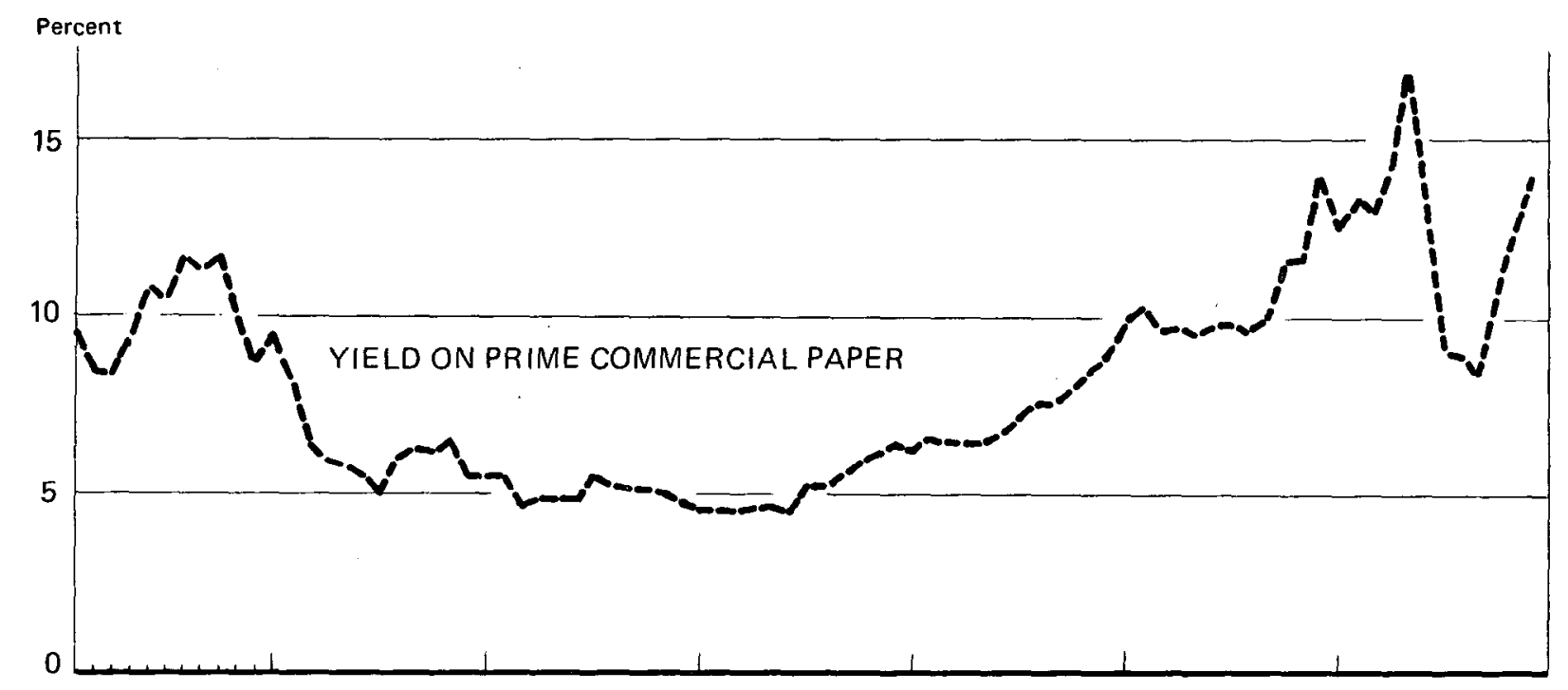

Basis Points

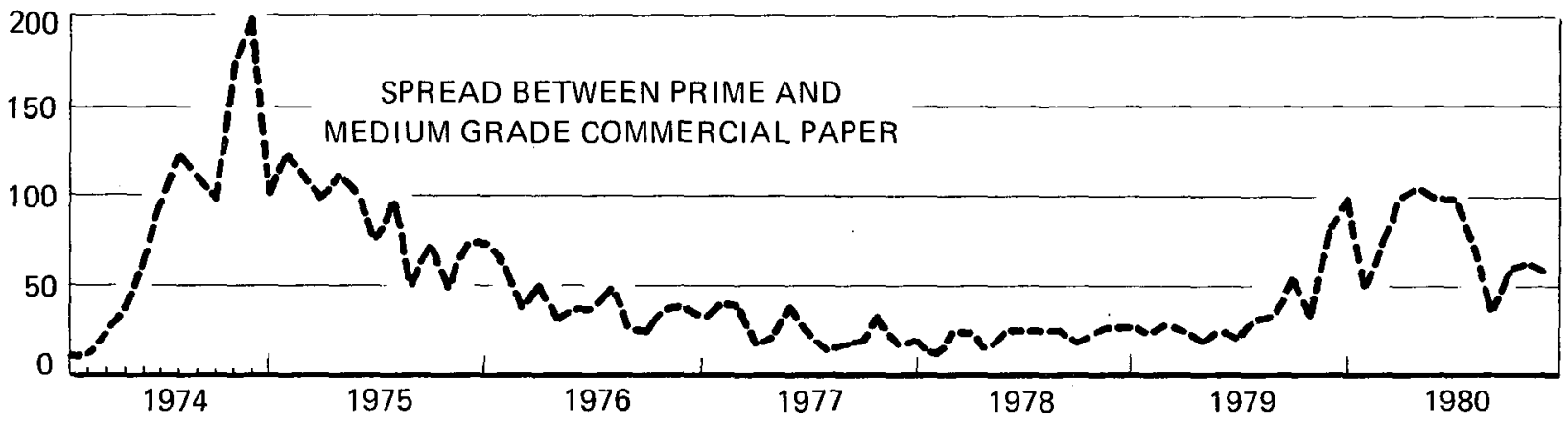

Source: Salomon Brothers.

relatively unchanged during this period of uncertainty. In gencral, the strongest paper issuers with prime ratings sold their paper without problems during the 1973-75 recession, although less financially sound issuers had to pay a premium to acquire funds in the commercial paper market.

The Late 1970s After the 1973-75 recession the commercial paper market grew rapidly. The volume of outstanding nonfinancial commercial paper expanded at a 31.9 percent compound annual rate from the first quarter of 1976 to the first quarter of 1980. Over the same period, nonbank financial paper grew at a 20.1 percent compound annual rate and bankrelated paper at a 27.9 percent annual rate. The number of commercial paper issuers increased substantially as well. For example, issuers rated by Moody's Investor Service increased from 516 at year-end 1975 to 881 at year-end 1980 .
The recent rapid growth in the commercial paper market owes much to the secular substitution of short-term for long-term debt, which accelerated because of the high rate of inflation in the late 1970s. Volatile interest rates due to uncertainty about the future rate of inflation make firms hesitant to structure their balance sheets with long-term, fixed rate assets and liabilities. In addition, because of inflation's debilitating effects on equity markets, debt has grown more than twice as fast as equity during the past decade. On the demand side, investors also have become wary of long-term fixed rate securities because of the uncertainty about the real rate of return on such commitments of funds. Therefore, funds have tended to flow away from the capital markets and into the money markets. A large share of these funds have been channeled into the commercial paper market. 
Nonfinancial Paper As nonfinancial firms acquired familiarity with open market finance during the 1970s, they gradually reduced their reliance on short-term bank loans. This is understandable since use of open market funds offers the potential for substantial savings to corporate borrowers compared to the cost of bank credit. Large commercial banks' primary source of funds for financing loans is the $\mathrm{CD}$ market, where interest rates are roughly equal to commercial paper rates. In addition, the cost of funds to commercial banks includes reserve requirements. ${ }^{6}$ Noninterest expenses associated with lending also add to the cost of bank operations. These various costs drive a wedge between open market and bank lending rates, and the spread between the prime rate and the commercial paper rate is a good proxy for the difference in financing costs facing companies that need funds.

Large, financially sound nonfinancial firms, therefore, have relied to an increasing extent on the commercial paper market for short-term credit. The ratio of nonfinancial commercial paper to commercial and industrial (C\&I) loans at large commercial banks, rose from about 11 percent in the mid-1970s to almost 25 percent in 1980 . Chart 3 shows the movements in the ratio of paper to loans from 1972 to 1980 .

Banks reacted to this loss of market share by becoming more aggressive in pricing loans. Since 1979, for example, some hanks have begun making loans below the prime rate. In a Federal Reserve Board survey of 48 large banks, the percentage of below prime loans rose from about 20 percent of all commercial loan extensions in the fourth quarter of 1978 to about 60 percent by the second quarter of 1980. Most of these loans were extended at rates determined by cost of funds formulas. In addition, the average maturity of loans over $\$ 1$ billion, which make up almost half of all C\&I loans in volume, fell from about 3 months in 1977 to a low of 1.2 months in August 1980. Loans below prime had an average maturity of well under one month. These below prime loans were in the same maturity range as the average maturity for commercial paper.

Aside from becoming more competitive with the commercial paper market, banks have tried at the

6 The following example illustrates how reserve requirements on CDs increases the cost of funds to banks. Suppose the reserve requirement against CDs is 3 percent and a bank's $C D$ offers a 12 percent yield. Then for every dollar obtained through the CD, only 97 cents are available to lend. The funds idled as reserves increase the effective cost of funds raised by issuing a $C D$. In this example, the additional cost imposed by the reserve requirement is 37 basis points, i.e., $12 \div .97=12.37$. same time to provide services to support their customers' commercial paper issues. Some banks have offered customers more flexible short-term borrowing arrangements to allow commercial paper issuers to adjust the timing of their paper sales. Morgan Guaranty Trust Company, which originated this service, calls its open line of credit a "Commercial Paper Adjustment Facility" and prices the service below the prime rate. Commercial banks also provide back-up lines of credit and act as issuing agents, as discussed above.

In summary, competition with the commercial paper market is changing the lending practices of commercial banks. Although banks still extend a large volume of short-term business loans, the profitability of loans to their largest customers has been reduced partly because of competition with the commercial paper market, and some commercial bank activity now focuses on supporting the issuance of their customers' commercial paper.

Financial Paper Since the 1920s, finance companies have been important participants in the commercial paper market. They provide much of the credit used to finance consumer purchases. Historically, around 20 percent of outstanding consumer credit has come from finance companies. Finance companies also supply a large and growing amount of business credit such as wholesale and retail financing of inventory, receivables financing, and commercial and leasing financing. About half of all the credit

Chart 3
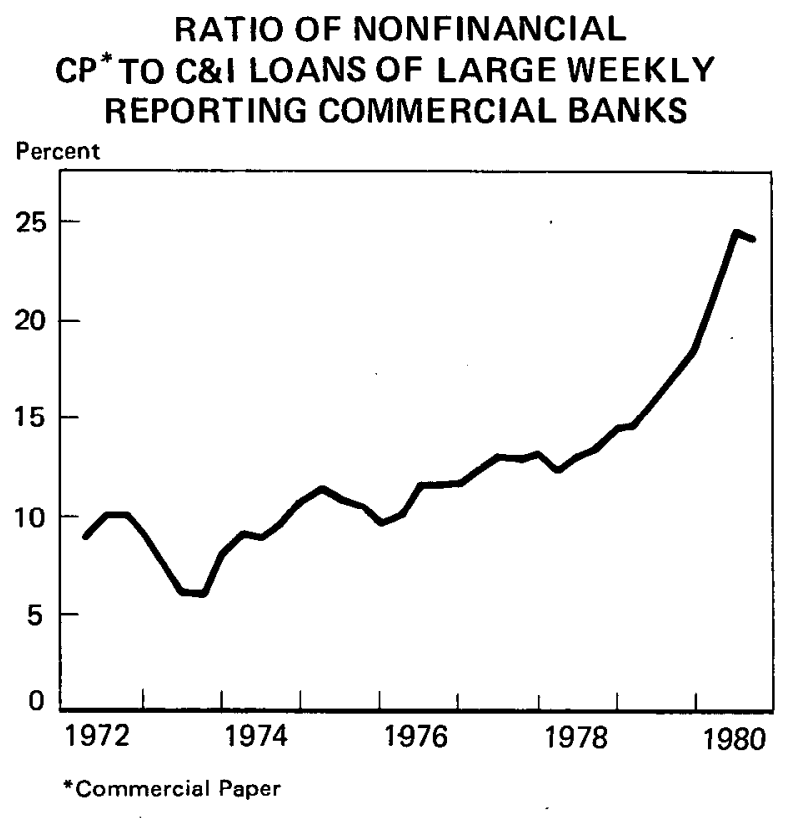

Source: Board of Governors of the Federal Reserve System. 
extended by finance companies goes to businesses, predominantly to small- and medium-sized firms.

The primary source of short-term funds for finance companies is sales of commercial paper. In fact, the outstanding commercial paper liabilities of finance companies were about five times as large as their bank loans in the late 1970s. Like nonfinancial companies, finance companies since the mid-1960s gradually increased the proportion of borrowing in the commercial paper market compared to short-term borrowing from commercial banks.

As seen in Chart 1, nonbank financial paper constitutes the largest proportion of outstanding commercial paper. Sixty percent of all commercial paper is directly placed and the greatest proportion of this is finance company paper. Finance company paper, however, is issued by only a small fraction of the total number of finance companies. According to the Fcderal Reserve Board's Survey of Finance Companies, 1975, 88 of the largest finance companies out of a total of about 3,400 such firms issued 97 percent of all finance company paper and extended 90 percent of total finance company credit.

The outstanding volume of bank-related financial paper has been extremely volatile compared to nonbank financial paper. As mentioned above, this market received a major jolt when the Federal Reserve imposed reserve requirements on bank-related commercial paper issues in August 1970. Growth in outstanding bank-related commercial paper resumed by mid-1971, however. This growth corresponded with record acquisitions of nonbank firms by bank holding companies, which peaked at 332 nonbank firms acquired in 1973 and 264 firms in 1974. Some of the primary activities of these newly acquired subsidiaries are commercial finance, factoring, and leasing. The 1973-75 recession curtailed the growth in bank paper, but growth resumed its upward trend by 1976 and has continued strongly since.

New Directions for the Commercial Paper Market Recently several new groups of issuers have entered the commercial paper market. These include foreign banks, multinational corporations, and public utilities; thrift institutions; second tier issuers relying on guarantees from supporting entities; and taxexempt issuers. These issuers have found the commercial paper market to be a flexible and attractive way to borrow short-term funds.

Foreign Issuers Foreign participation in the commercial paper market has been growing and will probably continue to be an important source of new growth. As of year-end 1980, Moody's rated 70 foreign issuers, which collectively had about $\$ 7$ billion in outstanding commercial paper. These issuers fall into three general categories: foreign-based multinational corporations, nationalized utilities, and banks. Some large foreign multinational corporations issue paper to finance their operations in the United States. Others borrow to support a variety of activities that require dollar payments for goods and services. Nationalized utilities have been major borrowers in the commercial paper market largely because their purchases of oil require payment in dollars. Finally, foreign banks raise funds for their banking activity or act as guarantors for the commercial paper of their clients by issuing letters of credit. These banks have been among the most recent entrants into the market.

The commercial paper market is often the cheapest source of dollars for foreign issuers. A major alternative source of dollar borrowing is the Eurodollar market, where rates are generally linked to the London Interbank Offered Rate (LIBOR). Many foreign banks, for example, obtain funds in the commercial paper market for $1 / 4$ percent or more below LIBOR. Aside from cost considerations, another important motivation behind foreign participation in the commercial paper market is foreign issuers' interest in obtaining ratings and gaining acceptance with the American financial community. The exposure from selling paper helps to broaden a foreign issuer's investor base and prepares the way for entering the bond and equity markets.

Two obstacles to foreign participation in the commercial paper market are obtaining prime credit ratings and coping with foreign withholding taxes on interest paid to investors outside the country. Ratings below top quality wipe out the cost advantage of raising short-term funds in the commercial paper market. To date, for example, no foreign banks have issued paper with less than top ratings.

Withholding taxes on interest paid to investors outside the country also may eliminate commercial paper's cost advantage over the Eurodollar market. These taxes are intended to curtail short-term capital outflows and are used in France, Belgium, Australia, Canada, and other countries. For foreign issuers' commercial paper to be marketable, the issuer must bear the cost of the withholding tax. The tax therefore raises the cost of acquiring funds using commercial paper.

By taking advantage of loopholes and technicalities in the withholding tax laws, foreign issuers often circumvent these laws. For example, the nationalized French electric company, Electricite de France, one 
of the largest foreign or domestic paper issuers, has its commercial paper classified as long-term debt, which is not subject to France's 15 percent withholding tax on interest. The reason for this classification is that the utility backs its paper with a 10-year revolving credit facility from its banks that establishes the commercial paper borrowing as long-term debt. French banks use a different approach to take advantage of a withholding tax exemption on shortterm time deposits like CDs. They set up U. S. subsidiaries to sell commercial paper and then transfer the proceeds to the French parent banks by issuing CDs to their U. S. subsidiaries.

In general, foreign issuers pay more to borrow in the commercial paper market than domestic issuers for two reasons. First, almost all foreign commercial paper issues have a sovereign risk associated with the issuer that results from additional uncertainty in the investor's mind about the probability of default on commercial paper because of government intervention, political turmoil, economic disruption, etc. This uncertainty creates a risk premium which increases the interest rate on foreign issues relative to domestic issues. The size of the premium depends on the issuer, the country, and the level of interest rates. A second source of additional costs arises when foreign issuers pay to establish and operate U. S. subsidiaries to issue paper and, in the case of foreign banks, incur reserve requirement costs on commercial paper issues. In addition, rating service fees are higher for foreign issuers than for domestic issuers, as mentioned earlier. Nevertheless, the commercial paper market is proving to be the least expensive source of short-term dollar funds for an increasing number of foreign borrowers.

Thrift Commercial Paper Both savings and loan associations and mutual savings banks have recently been allowed to borrow funds in the commercial paper market. Mutual savings banks (MSBs) had the authority to issue commercial paper, but faced restrictions on advertising, interest payments, and minimum maturity that effectively prevented them from issuing commercial paper. On March 3, 1980 the Federal Deposit Insurance Corporation (FDIC) removed the restrictions and thereby cleared the way for MSB participation in the commercial paper market. The FDIC ruled that MSB commercial paper must be unsecured, have a maximum maturity of nine months, sell at a minimum price of $\$ 100,000$, state that it is uninsured by FDIC, and bear a notice that the instrument will pay no interest after maturity. Despite the relaxation of restrictions, as of early 1981 no MSBs have issued paper. The failure of MSBs to issue commercial paper has been largely due to impaired MSB earnings, which make it difficult to obtain the high credit ratings necessary to realize the cost advantage in borrowing in the commercial paper market.

Savings and loan associations have had access to the commercial paper market since January 1979, when the Federal Home Loan Bank Board approved the first applications for S\&Ls to issue commercial paper and short-term notes secured by mortgage loans. S\&Ls use commercial paper principally to finance seasonal surges in loan demand and to finance secondary mortgage market operations. Commercial paper allows greater flexibility for S\&Ls in managing liquidity because they can borrow large amounts of cash quickly and for periods as short as five days. Relatively few S\&Ls carry commercial paper ratings. Of the 60 or so large S\&Ls expected to participate in the market after the FHLBB approved the first applications, only 12 had ratings from Moody's as of mid-1980, though all were P-1. These S\&Ls collectively had $\$ 327$ million in outstanding commercial paper as of mid-1980.

The attractiveness of commercial paper for S\&Ls and MSBs has been sharply diminished as a result of the Monetary Control Act of 1980 . Under the Act, commercial paper is considered a reservable liability, except when issued to certain exempt investors such as depository institutions. S\&Ls and MSBs have to hold reserves in the ratio of 3 percent against outstanding commercial paper, which is classified as a nonpersonal time deposit. Reserve requirements increase the cost of funds raised through commercial paper and consequently reduce the incentive for S\&Ls and MSBs to issue paper.

Support Arrangements Many lesser known firms gain access to the commercial paper market through financial support arrangements obtained from firms with the highest credit ratings. Second tier issuers frequently issue paper by obtaining a letter of credit from a commercial bank. This procedure substitutes the credit of a bank for that of the issuer and thereby reduces the cost of issuing commercial paper. This kind of support arrangement is known as "commercial paper supported by letter of credit" and resembles bankers' acceptance financing except that the issuance of commercial paper is not associated with the shipment of goods. Because the letter of credit is appended to the commercial paper note, commercial paper supported by letter of credit is alternatively referred to as a "documented discount note." Typically, letters of credit are valid for a specific term or are subject to termination upon written notice by 
either party. To have a commercial bank stand ready to back up an issue of paper, an issuer must pay a fee that ranges from one-quarter to threequarters of a percentage point.

Although commercial paper with letter of credit support reached an outstanding volume of about $\$ 2$ billion by mid-1980, this segment of the market is still comparatively small. Many issuers of letter of credit commercial paper are subsidiaries of larger corporate entities. These second tier issuers include firms involved in pipeline construction, vehicle leasing, nuclear fuel supply, and power plant construction. Other commercial paper issuers also have acquired letter of credit support from commercial banks, particularly during the period of restricted credit growth in early 1980 . Issuers whose ratings were downgraded faced difficulty selling their paper and paid substantial premiums over high grade paper. Buying a letter of credit from a commercial bank reduced their borrowing costs in the commercial paper market and still offercd a cheaper alternative to short-term bank loans.

Other supporting entities that provide guarantees or endorsements are insurance companies, governments for government-owned companies, and parent companies for their subsidiaries. For example, the commercial paper of the nationalized French utilities, such as Electricite de France, carries the guarantee of the Republic of France. Guarantees or endorsements by parent companies for their subsidiaries are the most prevalent form of support arrangement.

Tax-Exempt Paper One of the most recent innovations in the commercial paper market is tax-exempt paper. Except for its tax-exempt feature, this paper differs little from other commercial paper. To qualify for tax-exempt status the paper must be issued by state or municipal governments, or by qualified nonprofit organizations. Like taxable commercial paper, tax-exempt paper is also exempt from Securities and Exchange Commission registration provided the paper matures within 270 days. Most tax-exempt paper matures within 15 to 90 days. These shortterm debt obligations are alternatively known as short-term revenue bonds or short-term interim certificates.

The outstanding volume of tax-exempt paper has grown rapidly, rising from an insignificant amount in 1979 to about $\$ 500$ million in 1980 . It will probably exceed $\$ 1$ billion in 1981. Much of the demand for tax-exempt paper comes from short-term taxexempt funds, which had assets of $\$ 1.5$ billion in mid-1980, and from bank trust departments. Many mutual fund groups are setting up tax-exempt money market funds in response to the apparent increasing demand for this type of investment. A current shortage of tax-exempt commercial paper has depressed the yields on outstanding issues, making this instrument especially attractive to tax-exempt issuers. However, constraints on public agency use of shortterm debt in some states may continue to limit the supply of tax-exempt commercial paper.

Conclusion. The commercial paper market has served the short-term financing needs of several groups of borrowers to an increasing degree in recent years. Many nonfinancial companies, especially large firms, have substituted commercial paper for shortterm bank loans to satisfy their working capital requirements. Commercial paper has generally been a less costly financing alternative than bank short-term credit for these firms. Finance companies have relied to a greater extent on commercial paper than nonfinancial companies for short-term financing and have issued the greatest proportion of outstanding commercial paper. Most large finance companies realize economies of scale by placing commercial paper directly with investors. Bank holding companies also have depended on the paper market to finance their banking-related activities, which increased in size and scope during the 1970 s.

Other types of issuers have been recently attracted to the commercial paper market because of the potential saving in interest costs over alternative ways of borrowing short-term funds. Foreign issuers have sold a substantial amount of commercial paper since entering the market in the mid-1970s. Foreign and domestic issuers who lack sufficient financial strength to offer commercial paper on their own have gained access to the market via support arrangements with stronger financial or corporate entities. Tax-exempt issuers are expected to increase in number and generate larger supplies of tax-exempt paper. Thrift institutions, on the other hand, probably will not make much use of the market in the future because recently imposed reserve requirements on commercial paper have reduced its cost-advantage over other sources of short-term credit.

Many investors find commercial paper to be an attractive short-term financial instrument. Although corporations and other institutional investors held most outstanding commercial paper in the past, financial intermediation by money market funds and other short-term investment pooling arrangements has given many new investors, especially individuals, indirect access to commercial paper. 


\section{References}

1. "A Way to Upgrade Corporate IOUs." Business Week, March 31, 1980.

2. Board of Governors of the Federal Reserve System. "Short-Term Business Lending at Rates Below the Prime Rate." Federal Monetary Policy and Its Effect on Small Business, Part 3. Hearings before a Subcommittee on Access to Equity Capital and Business Opportunities of the House Committee on Small Business. U. S. Congress, House. Committee on Small Business, 96th Cong., 2nd sess., 1980, pp. 318-327.

3. Chell, Gretchen. "Tax-Exempt Commercial Paper Beginning to Catch on as an Investment Medium." The Money Manager, July 21, 1980.

4. "Domestic Financial Statistics." Federal Reserve Bulletin, various issues.

5. "FDIC Eases Curbs on Mutuals Issuing Commercial Paper." American Banker, February 7, 1980.

6. Grant, James. "Crowding Out Chrysler ... News in Commercial Paper." Barrons, August 4, 1980.

7. Greef, Albert O. The Commercial Paper House in the United States. Cambridge: Harvard University Press, 1938.

8. Hildebrand, James L. "Enter Euro-Commercial Paper." Euromoney, July 1980.

9. Hurley, Evelyn M. "Survey of Finance Companies, 1975." Federal Reserve Bulletin (March 1976).

10. "The Commercial Paper Market." Federal Reserve Bulletin (June 1977).

11. Judd, John P. "Competition Between the Commercial Paper Market and Commercial Banks." Economic Review, Federal Reserve Bank of San Francisco (Winter 1979).
12. Levin, Sumner N., ed. The 1979 Dow Jones-Irwin Business Almanac. Homewood, Illinois: Dow Jones-Irwin, 1979.

13. McKenzie, Joseph A. "Commercial Paper: Plug ging into a New and Stable Source of Financing." Federal Home Loan Bank Board Journal (March 1979), pp. 2-5.

14. Moody's Commercial Paper Record. Monthly Statistical Supplement. Moody's Investors Service, Inc. (November 1980).

15. Moody's Commercial Paper Record. Quarterly Reference Edition. Moody's Investors Service, Inc. (Fall 1980)

16. Nevins, Baxter D. The Commercial Paper Market. Boston: The Bankers Publishing Company, 1966.

17. Puglisi, Donald J. "Commercial Paper: A Primer." Federal Home Loan Bank Board Journal, 13 (December 1980) : 4-10.

18. Quint, Michael. "Short-Term, Below-Prime Rates to Big Customers Seem Permanent." American Banker, May 2, 1978.

19. "Banks Give Paper Issuers New Backup." American Banker, September 27, 1978.

20. "Selling Paper Abroad to Skirt a Ratings Cut." Business Week, September 22, 1980.

21. Stigum, Marcia. The Money Market: Myth, Reality, and Practice. Homewood, Illinois: Dow Jones-Irwin, 1978.

22. "The New Dynamics of the Market for Business Credit." The Morgan Guaranty Survey. March 1978, pp. 6-11.

23. "The Rush Into U.'S. Paper." Business Week, January 26, 1981.

The Economic Review is produced by the Research Department of the Federal Reserve Bank of Richmond. Subscriptions are available to the public without charge. Address inquiries to Bank and Public Relations, Federal Reserve Bank of Richmond, P. O. Box 27622, Richmond, Virginia 23261. Articles may be reproduced if source is given. Please provide the Bank's Research Department with a copy of any publication in which an article is used. Also note that microfilm copies of the Economic REview are available for purchase from University Microfilms, Ann Arbor, Michigan 48106. The identification number is 5080 . 


\title{
1980: A DIFFICULT YEAR FOR FARMERS
}

\author{
Sada L. Clarke
}

While many factors influenced the financial and credit conditions of Fifth District farmers in 1980, three provided the major keys to the final story for the year. These three were:

- The severe drought and searing temperatures which reduced crop output substantially and disrupted livestock production.

- The sharply higher prices of farm production inputs relative to the prices of farm products that exerted significant downward pressure on net farm income.

- The unusually high interest rates, especially during the spring planting season.

The three factors combined to reduce farmers' ability to service loans needed to buy farm operating inputs and to make capital investments. This situation caused many to reduce the use of purchased inputs and to delay the purchase of machinery and equipment.

Moreover, commercial banks early in the year were faced with credit controls and some evidence of rising liquidity pressures, factors that reduced their ability to provide loan funds early in the planting season. Many farm borrowers, particularly in drought-stricken areas, had loan repayment difficulties, and many had to request loan renewals or extensions, causing the quality of farm loans to deteriorate. All in all, it seems certain that many Fifth District farmers, and farm lenders alike, will remember 1980 as a difficult year.

Drought - A Major Cause of Farmers' Woes Farmers' financial conditions in 1980 varied, to a large extent, according to the severity of the drought in their area. Some were hit extremely hard. A few, however, will probably be able to count it a fairly good year. But when cash returns from marketing all crops and livestock are added together and the high production costs deducted, it is expected that farmers' net income in 1980 will show a sizable decline from that in 1979.

Geographically, the drought was widespread, with the most extensive damage apparently occurring in the Carolinas, Virginia, and to a lesser degree in Maryland. West Virginia appears to have had few problems with the dry weather. The severity of the drought also varied from area to area within the states. Farmers in the Northern Coastal Plain, where most of the peanuts are grown, and in the Southern Piedmont felt the brunt of the drought in North Carolina, for example. Coastal Plain and Piedmont producers were also hardest hit in Virginia.

The influence of last summer's dry, hot weather on local farm production, income, and credit conditions in 1980 was extremely unfavorable. The drought's role in causing sharp reductions in crop output, for example, was of unusual scope and severity. Yields per acre fell drastically, leading to sharp cutbacks in production. Four major cropspeanuts, soybeans, corn, and cotton-suffered the biggest declines. But there were also significant reductions in the output of all small grains except wheat, fire-cured tobacco, Irish potatoes, and sweet potatoes. While the peach and apple crops were only slightly below the previous season, dry weather limited the sizing of the fruit. There was also only a slight decline in the production of hay because the sharply larger output in West Virginia all but offset the smaller crops in other states.

Last year was an unusually poor year for the District's peanut farmers. Serious drought damage cut both yields per acre and overall production 35 percent below 1979 levels. Moreover, a fairly sizable proportion of the crop did not make edible grade because of poor quality. With short supplies, peanut prices rose sharply above loan levels, but the many growers who sold or contracted their peanuts early may not have benefited from the price increases.

Soybean producers fared almost as badly as the peanut farmers. Drought-reduced output and peracre yields were both 32 percent under those in 1979. Yields on some farms were so low that the soybeans were cut for hay. This season's higher prices, although not as high as had been anticipated earlier, are helping to offset some of the sharp increase in production costs.

Feed grain producers, especially corn growers, came through the year in a little better condition than the peanut and soybean farmers. Even so, drought cut the total size of the crop by 25 percent 
and yields per acre even more. With short supplies and record disappearance (domestic use plus exports) anticipated, this season's corn prices at the farm are running well above last season's level. But the higher prices may not be able to offset the sharply smaller crop and increased costs of production.

Cotton farmers no doubt will also remember 1980 as a very poor year. Hit hard by the unfavorable growing conditions, yields per acre were down 33 percent. So, despite a 19 percent increase in acreage harvested, total cotton production dropped 20 percent below the 1979 harvest. Most cotton producers will probably receive some benefit from the higher prices this season, however.

Flue-cured tobacco growers-compared with the peanut, soybean, corn, and cotton producers-came through the year in fairly good shape. The hot, dry growing season that reduced the quality of the fluecured crop was probably the most notable development of the year. Total production rose 16 percent from year-earlier levels in response to the 5 percent increase in yields per acre and an 11 percent larger acreage. Season average prices for the flue-cured crop were up 4 percent over 1979 to set a new record. The value of gross sales was 20 percent above 1979; however, costs of producing the 1980 crop were sharply higher and may have resulted in lower net returns to producers.

The drought also had its effects on livestock and poultry producers. With the reduced feed grain output, the price of corn and feed concentrates increased rapidly last summer and fall, boosting feed costs and hence the costs of production significantly. Moreover, the searing temperatures that accompanied the drought conditions caused thousands of broilers to die and reduced rates of gain. With broiler prices below the costs of production in the first half of 1980 , broiler producers were in an unfavorable financial situation. But after mid-1980, broiler prices rose faster than costs, making production profitable. Egg producers, on the other hand, remained in a cost-price squeeze throughout the year, so they were in an unfavorable financial situation during most of 1980.

The overall financial condition of hog producers last year was mixed. With low hog prices during the first half of the year, producers' incomes were generally less than their cash expenses so meeting their cash-flow commitments was a problem. Improved hog prices during the second half brought some relief from cash-flow difficulties, but net returns increased only marginally because of the higher feeding costs.
Most cattle feeders experienced losses on fed cattle marketed during the first half of 1980 . Fed cattle prices strengthened in the second half, however, more than offsetting the higher costs for feed and calves and bringing increased returns during the final quarter of 1980.

Dairymen who were not adversely affected by last summer's drought remained in a strong financial condition in 1980. Slightly larger milk production and higher support prices for manufacturing milk increased income from dairying to a level that mostly offset the steadily rising costs of production. The financial condition of dairymen whose pastures, hay, and other feed crops were damaged by drought was, of course, much less favorable.

A Tightening Cost-Price Squeeze The severity of last year's squeeze between farm costs and prices was a major factor determining farmers' financial conditions. On average, however, it was actually the soaring production costs, not falling farm prices, that caused 1980's relatively low net farm income. While prices paid by farmers for production items, interest, taxes, and wage rates jumped some 12 percent over 1979 levels, farm product prices averaged only about 2 percent higher. Farmers, in fact, had to pay higher prices for all items of production except feeder livestock.

While last year's big jump in production costs can be attributed to fairly sizable price increases for nearly all costs of production, there were five major culprits-namely, fuels and energy, interest, fertilizer, agricultural chemicals, and farm and motor supplies, in that order. Fuel and energy prices took the biggest leap, rising some 38 percent over 1979 . This price increase not only caused farmers to have to spend more money to run their machinery and equipment, but it also pushed up the prices of fertilizer and chemicals. Fertilizer prices, in turn, jumped 24 percent over the 1979 price level, and prices of agricultural chemicals climbed 17 percent. Meanwhile, interest charges rose some 25 percent over 1979 rates, reaching historic highs. Farm and motor supplies advanced 17 percent as did prices for farm chemicals. Sizable price gains for two other important production items also took more money out of farmers' pockets-for example, a 13 percent increase in the price of feed and a 12 percent upturn in the prices of tractors and self-propelled machinery.

There is little doubt that all farmers felt the pinch of the cost-price squeeze last year. But of course it was more painful for some than for others. For the many crop farmers whose incomes were greatly 
reduced by drought, the squeeze was no doubt exceedingly painful. It was also a rough experience for many livestock and poultry producers, especially during the first half of 1980 when prices received for feeder cattle, hogs, broilers, and eggs were generally below year-earlier levels. For many of these producers, prices for their products were below the costs of production. Furthermore, the severity of the costprice squeeze reportedly was expected to force many small farmers, including many small, nonmechanized tobacco growers, out of the farming business in 1980.

Interest Rates Volatile Bank interest rates charged on farm loans last year were unusually volatile, moving up and down from quarter to quarter as if they were on a roller coaster. The average rates charged on loans to farmers virtually skyrocketed during the first quarter, shooting up 3.5 percentage points over the previous quarter and 5.6 percentage points from a year earlier. With this surge, interest rates rose to record levels, and farmers found themselves having to pay an average of 16.6 percent interest to obtain a bank loan.

The trend in interest rates reversed in the second quarter and actually dropped almost as sharply as they had risen in the previous quarter. Then, after edging upward slightly during the third quarter, bank rates on farm loans soared again during the last quarter, hitting new highs that averaged 16.9 percent. Rates varied by type of loan from quarter to quarter, with interest charges on farm operating loans showing the largest year-to-year increase.

But average interest rates do not tell the whole story. Increasingly, as more bankers began pricing their farm loans at variable rates, many District farmers found themselves having to pay the prime rate, plus 1 or 2 percent.

Last year's interest rates forced many farmers into having to make some agonizing decisions: Whether to borrow or not to borrow was the big question. Many farmers who would have had to obtain loan funds to purchase "big ticket" items, such as machinery and equipment, decided against buying in 1980. Some had to make the decision to reduce the purchase of fertilizer, an item usually bought on time.

Farm Loan Demand Weak Because of the extremely high interest rates and the high and rising costs of production, the demand for farm loans remained weak throughout the year, particularly so at commercial banks. Bankers noted a continued weakening in the demand for farm loans as the year pro- gressed, with the siowdown accelerating in the fourth quarter. Farmers apparently stayed away from loan windows in large numbers, since loan demand each quarter was reported to be well below year-earlier levels.

Even though interest rates at production credit associations and Federal land banks were lower than those at banks, there was also a decided slowdown in the rate of farm loan demand at these lending institutions. The pace of new farmer borrowing from PCAs and the FLBs slackened during the first half of 1980 and then fell below year-earlier levels in the second half-PCAs by 5 percent and the FLBs by 28 percent.

The generally weaker loan demand by farmers last spring and summer was most unusual. But there is little doubt that the situation helped to improve the liquidity conditions of banks heavily involved in farm lending. This slack in farmer borrowing appears to have resulted from many factors. The most obvious, perhaps, were these :

- High interest rates that caused some farmers, normally bank customers, to shift their loan demand to PCAs where funds were available at lower rates of interest.

- Many farmers voluntarily cut back on their purchases-and hence the need for borrowed fundsbecause soaring production costs and depressed prices for many farm commodities were reducing expectations for a break-even year, much less a profitable one.

- The Special Credit Restraint Program, particularly the misunderstandings pertaining to it, surely played a significant role in reducing the demand for non-real-estate farm loans at banks during the spring quarter.

The continued weakness in farm loan demand in the third and fourth quarters, however, would appear to have been related largely to:

- The serious cash-flow problems that many farmers were experiencing-problems that reduced their ability to repay outstanding loans and made them hesitant to assume additional debt.

- Moreover, widespread areas of the District were declared drought disaster areas, so many farmers became eligible for disaster loans from the Farmers Home Administration and/or the Small Business Administration at lower rates of interest.

- And, as one banker pointed out, "Current high interest rates have caused farmers to take a wait-andsee attitude." 
Supplies of Loanable Funds Ample Bank supplies of farm loan funds in the Fifth District. remained relatively ample throughout the period of the expected crunch last spring, although credit was extremely tight in some parts of the country. There was a little evidence that some banks heavily involved in farm lending were faced with liquidity pressures in the spring, yet the supply of production credit seemed adequate to meet demand in most sections of the District. But in an effort to help farmers obtain loan funds at better rates of interest, one-third of the bankers reporting said they referred would-be borrowers to nonbank credit agencies in above-normal numbers.

With the generally weaker farm loan demand evident in the first quarter continuing throughout the year, the aforementioned liquidity pressures eased. Bank supplies of farm loan funds improved from both the spring quarter and year-ago levels during the second quarter, showed further improvement in the third quarter, and remained at that improved position during the final quarter of the year. Moreover, from one-fifth to one-fourth of the survey respondents in each of the last three quarters indicated that funds available for lending to farmers were greater than usual.

Other conditions also pointed to the improved availability of farm loan funds at banks during the last nine months of 1980 . The best indication, perhaps, occurred in the second quarter when not a single District bank-member or nonmember-took advantage of the opportunity to borrow from the Federal Reserve Bank's discount window under the Fed's temporary, simplified seasonal loan program implemented in April.

Repayments Down, Renewals Up Measured in terms of loan repayment rates and loan renewals, the quality of farm loans held by banks deteriorated significantly during 1980 . While the declining quality of farm loan portfolios represented problems for many bankers throughout the year, these problems intensified as the harvest season progressed. By the fourth quarter, the combination of drought-reduced crop output and income and one of the tightest costprice squeezes in years had created cash-flow prob- lems for many Fifth District farmers. Bankers, as a result, experienced much slower loan repayment rates and a sharper increase in requests for loan renewals than in the same period a year earlier. Not only was the quality of farm loans held by banks much poorer than at the same time in 1979 , but it was also well below the level in 1977 when drought-reduced farm income also plagued District farmers.

Because of current farm financial and credit conditions, some refinancing of farm loans will be necessary. Some farmers reportedly will have to obtain the second disaster loan in recent years from the Farmers Home Administration or the Small Business Administration or sell out.

In Summary Last year was, indeed, a difficult year for Fifth District farmers. It was also a year that many farmers would like to forget. As one South Carolina banker described the situation, "Bad weather, inflation, and high interest rates combined made 1980 the worst year for farmers in recent history." Because of the need to obtain renewals and extensions of existing loans, many farmers in the drought-stricken areas are heavily burdened with debt. Some have experienced losses for three out of the last four years, and for them conditions seem bleak. Fortunately, however, the situation is not as grim for all farmers. Those not affected by last year's adverse weather, the better managers, and those with other resources to fall back on remain in a strong financial condition.

In view of the heavy financial losses experienced by many Fifth District farmers in 1980, it is encouraging to note that the agricultural outlook for 1981 is much more promising. Higher farm prices and improved farm income are expected because of tighter supply conditions. Gross farm income promises to increase substantially, rising more than production costs. Under this set of circumstances, net farm income will probably rebound from last year's level and may recover all of 1980's losses. Of course, the full realization of these prospects will depend, to a great extent, on whether growing conditions are more nearly normal and on whether higher farm prices materialize as expected. 